This is a post-peer-review, pre-copyedit version of an article published in Journal of Applied Phycology. The final authenticated version is available online at: https://doi.org/10.1007/s10811-019-01858-x.

\title{
ANAEROBIC CO-DIGESTION OF OLIVE MILL SOLID WASTE AND MICROALGA Scenedesmus quadricauda: EFFECT OF DIFFERENT CARBON TO NITROGEN RATIOS ON PROCESS PERFORMANCE AND KINETICS
}

\author{
M.J. Fernández-Rodríguez ${ }^{1,2}$; D. De la Lama-Calvente ${ }^{1}$; A. Jiménez-Rodríguez ${ }^{2}$; \\ R. Borja ${ }^{1}$; B. Rincón-Llorente ${ }^{1 *}$. \\ ${ }^{1}$ Instituto de la Grasa (CSIC), Campus Universidad Pablo de Olavide. Edificio 46. \\ Ctra. de Utrera Km. 1, 41013 Sevilla, Spain. \\ ${ }^{2}$ Departamento de Sistemas Físicos y Naturales, Universidad Pablo de Olavide. Ctra.de \\ Utrera, km 1, 41013 Sevilla, Spain. \\ e-mail of the corresponding author*: brlloren@cica.es
}

\begin{abstract}
Anaerobic digestion (AD) is one of the most efficient processes for treating agri-food waste in order to obtain renewable energy. Olive mill solid waste (OMSW) is the main residue from the two-phase olive oil manufacturing process; it has a high organic content and high $\mathrm{C} / \mathrm{N}$ ratio, which hinders its $\mathrm{AD}$, giving low methane yield. In the present study, a microalga, Scenedesmus quadricauda (S. quadricauda), was used as co-substrate for the AD of OMSW to compensate for its nitrogen deficiency. The robustness and the high growth rate of $S$. quadricauda make this microalga a potential source of nitrogen to co-digest with carbonrich substrates. Different co-digestion mixtures of OMSW-microalgae and the single substrate were tested. For all co-digestion mixtures, the alkalinity value at the end of the experiment remained below $4889 \pm 245 \mathrm{mg} \mathrm{CaCO}_{3} / \mathrm{L}$ and $\mathrm{pH}$ in the range of 7.50-7.67 indicating stability and good process performance. The results showed the highest methane yield $\left(461 \mathrm{~mL} \mathrm{CH}_{4}\right.$
\end{abstract}


$\mathrm{STP} / \mathrm{g}$ VS added) for the co-digestion mixture $75 \% \mathrm{OMSW}-25 \%$ S. quadricauda $(\mathrm{C} / \mathrm{N}=25.3)$, which was 104 and $23 \%$ higher than that obtained from the single microalga $(\mathrm{C} / \mathrm{N}=5.6)$ and OMSW ( $\mathrm{C} / \mathrm{N}=31.9)$, respectively. No ammonia inhibition was detected despite the high protein content of the microalgae. The transference function model allowed for adequately fitting the experimental results of methane production with time in the anaerobic experiments. The highest maximum methane production rate, $R_{m}$, among the different co-digestion mixtures assayed was obtained for the mixture $75 \%$ OMSW-25\% S. quadricauda with a value of $89 \mathrm{~mL} \mathrm{CH}_{4} /(\mathrm{g} \mathrm{VS} \mathrm{d})$.

Keywords: Scenedesmus quadricauda; olive mill solid waste; anaerobic co-digestion; methane; biochemical methane potential; kinetics.

\section{INTRODUCTION}

The Mediterranean culture has always been linked to the consumption of olive oil, and countries in Southern Europe, North Africa and the Middle East are its main producers. Within these countries, Spain is worth mentioning as the main producer and exporter of olive oil worldwide. The main problem of olive oil production is the generation of highly-polluting by-products which cause several environmental problems (Rincón et al., 2008).

At the beginning of the 90 s, oil mills began to establish a new system for the extraction of olive oil by two-phase centrifugation. The two-phase olive oil system contributed to an improvement in the quality of the product and a marked decrease in the use of water during the process. Currently, more than $90 \%$ of Spanish olive oil industries have implemented the more sustainable two-phase system, even though 800 
$\mathrm{kg}$ of the main waste are still produced for each tonne of processed olive (Fernández Rodríguez et al. 2014). The main by-product generated from this system is the olive mill solid waste (OMSW). The large amount of OMSW produced every year, generates several environmental problems (Khatib et al. 2009); not only because of the large amount generated, but also because of its characteristics and chemical composition. OMSW is a lignocellulosic byproduct characterized by its high organic content and phenolic compounds. There are several experimental treatments for OMSW, which have the potential to make it re-usable as fertiliser and water for irrigation or to obtain valuable materials from it such as, proteins, minerals and polysaccharides (Pantziaros et al. 2018; Sousa et al. 2018). However, the reuse of OMSW is restricted by the abundance of complex compounds it contains and its elevated polluting load. Anaerobic digestion $(\mathrm{AD})$ is the most viable treatment option because of its advantages related to energy production, high chemical mineralization and low sludge production (Rincón et al. 2008).

$\mathrm{AD}$ of organic waste has been applied extensively for decades to produce biogas and several studies of AD on the OMSW have been reported (de la Lama et al. 2017; Gunay and Karadag 2015). However, using OMSW as the sole substrate is not recommended due to its nutritional imbalance (Fernández Rodríguez et al. 2014). OMSW is a recalcitrant substrate that has a low methane potential due to its lignocellulosic content (Maamir et al. 2017). Hydrolysis of lignocellulosic wastes, such as OMSW, is often the rate-limiting step in anaerobic processes (Wang et al., 2006). There are several methods to enhance the destruction of the biopolymers and complex substances in order to increase biogas production. Anaerobic co-digestion of two substrates is proposed in the present study to maximize biogas production. The benefits of co-digestion lie in balancing the $\mathrm{C} / \mathrm{N}$ ratio in the co-substrate mixture, as well as 
macro and micronutrients, $\mathrm{pH}$, inhibitors/toxic compounds and also accelerating the hydrolysis process (Barua et al. 2019). As benefits of co-digestion Ajeej et al. (2015) reported an increased activity of methanogenic bacteria, a decrease in AD inhibition by ammonium and even an increase in cellulose activity when carbon-rich materials were added.

The addition of nitrogen-rich biomass, such as microalgae, could balance the $\mathrm{C} / \mathrm{N}$ ratio, thus accelerating the hydrolytic phase and providing a constant concentration of nitrogen to the substrate. Some studies have been carried out with the aim of investigating the best performance of anaerobic co-digestion based on $\mathrm{C} / \mathrm{N}$ ratio optimization (Fernández-Rodríguez et al. 2014; Ambarsari et al. 2018; Xie et al. 2018; Nguyen et al. 2018). For instance, Fernández-Rodríguez et al. (2014) reported a maximum methane yield when a mixture between OMSW and the microalga Dunaliella salina had a $\mathrm{C} / \mathrm{N}$ close to $26.7 / 1$.

The feasibility of using algal biomass cultivated with wastewater adds more value to these studies due to a combination of nutrient removal from wastewater with $\mathrm{CO}_{2}$ fixation which provides an economically viable system. On the one hand, there are studies that show the capacity for growing microalgae in wastewater and achieving a maximum COD removal efficiency of $72.3 \%$ (Xu et al. 2015). On the other hand, microalgae can be used as co-substrate in an approach to dilute complex compounds and balance the $\mathrm{C} / \mathrm{N}$ ratio.

Scenedesmus is one of the most common genera of Chlorophyta, and is characterized by a rigid, sugar cell wall (Takeda 1996). It is one of the most commonly used microalgae due to its plasticity, its potential for rapid growth and ability to grow in different environments. There are numerous studies that support the robustness and fast 
growth of this genus in wastewater, and its effectiveness in removing a high percentage of nutrients from wastewater treatment plants (Xiao et al. 2011; Wong et al. 2015). There are even studies that characterize Scenedesmus as a genus able to bio-accumulate lipids, highly-degradable organic compounds during anaerobic digestion (Rincón et al. 2018).

Therefore, the aim of this study was to evaluate the stability of the system, its energy recovery potential and macronutrient $(\mathrm{N})$ removal from the various co-digestion mixtures of OMSW and Scenedesmus quadricauda (S. quadricauda) in order to study the potential of the robust and fast growing microalgae $S$. quadricauda as feedstock for co-digestion with OMSW in batch experiments. The influence of the percentage of each co-substrate on the kinetics of the anaerobic process and ultimate methane yield was also evaluated in biochemical methane potential (BMP) tests. BMP is a procedure developed to determine the methane production of a given organic substrate during its anaerobic decomposition. The BMP assay has proved to be a relatively simple and reliable method to obtain the extent and rate of organic matter conversion to methane. The information provided by BMP is valuable when evaluating potential substrates and for optimizing the design and functioning of an anaerobic digester. Literature related to BMP assays is extensive showing that this test has been used to evaluate a wide variety of substrates (Holliger et al., 2016).

\section{MATERIALS AND METHODS}

\section{Two-phase olive mill solid waste}


The two-phase OMSW used in the experiments was collected from the Experimental Olive Oil Mill Factory located in the 'Instituto de la Grasa (CSIC)', Seville (Spain). Before use, the OMSW was sieved through a $2 \mathrm{~mm}$ mesh for removing pieces of olive stone. Some of the characteristics of the OMSW used in the experiments were shown in Table 1.

\section{Microalgal strain and cultivation}

The Chlorophyta S. quadricauda was grown at $25{ }^{\circ} \mathrm{C}$ in BG11 medium (Rippka et al. 1979). The algal biomass was cultivated during two weeks under $12: 8$ light : dark cycles in an AGP-700-ESP incubator chamber (Rdiber S.A., Barcelona, Spain) with illumination provided by 6 fluorescent lamps (36 W). Periodically microscope observations were carried out to ensure that the algae culture was composed mainly of Scenedesmus sp. The cells from the culture were concentrated by centrifugation ( $5 \mathrm{~min}$ at $3.500 \mathrm{rpm})$. Finally, microalgal biomass was placed in liquid nitrogen $\left(-196^{\circ} \mathrm{C}\right)$ and stored at $-80^{\circ} \mathrm{C}$. Some characteristics of the algal biomass used in the experiments were also shown in Table 1.

\section{Inoculum for anaerobic digestion}

The inoculum was obtained from an industrial upflow anaerobic sludge blanket (UASB) reactor which treats brewery wastewater located in Sevilla (Spain). The main characteristics of the inoculum used were summarized in Table 1.

\section{Experimental procedure}

The test was carried out in a multi-batch reactor system. The effective volume of the reactors was $250 \mathrm{~mL}$. The BMP test was performed in triplicate and the reactors 
were continuously agitated by magnetic bars at $500 \mathrm{rpm}$ and placed in a thermostatic water bath at mesophilic temperature $\left(35 \pm 2{ }^{\circ} \mathrm{C}\right)$.

The inoculum-to-substrate ratio was 2 (VS basis). A solution of trace elements was added to each reactor containing $239 \mathrm{~mL}$ of inoculum and the required amount of substrate. The composition of the solution of trace elements was: $\mathrm{FeCl}_{2} \cdot 4 \mathrm{H}_{2} \mathrm{O}, 2000$ $\mathrm{mg} / \mathrm{L} ; \mathrm{CoCl} 2 \cdot 6 \mathrm{H}_{2} \mathrm{O}, 2000 \mathrm{mg} / \mathrm{L} ; \mathrm{MnCl} 2 \cdot 4 \mathrm{H}_{2} \mathrm{O}, 500 \mathrm{mg} / \mathrm{L} ; \mathrm{AlCl}_{3} \cdot 6 \mathrm{H}_{2} \mathrm{O}, 90 \mathrm{mg} / \mathrm{L}$; $\left(\mathrm{NH}_{4}\right) 6 \mathrm{Mo}_{7} \mathrm{O}_{24} \cdot 4 \mathrm{H}_{2} \mathrm{O}, 50 \mathrm{mg} / \mathrm{L} ; \mathrm{H}_{3} \mathrm{BO}_{3}, 50 \mathrm{mg} / \mathrm{L} ; \mathrm{ZnCl}_{2}, 50 \mathrm{mg} / \mathrm{L} ; \mathrm{CuCl}_{2} \cdot 2 \mathrm{H}_{2} \mathrm{O}, 38$ $\mathrm{mg} / \mathrm{L}, \mathrm{NiCl}_{2} \cdot 6 \mathrm{H}_{2} \mathrm{O}, 50 \mathrm{mg} / \mathrm{L}, \mathrm{Na}_{2} \mathrm{SeO}_{3} \cdot 5 \mathrm{H}_{2} \mathrm{O} 194 \mathrm{mg} / \mathrm{L}$ and EDTA $1000 \mathrm{mg} / \mathrm{L}$. As controls, three $250 \mathrm{~mL}$ batch reactors were supplied with the inoculum and trace elements solution but without the addition of substrate.

The reactors were sealed and the headspace of each flask was flushed with nitrogen at the beginning of the assay. The produced biogas was passed through a $3 \mathrm{~N}$ $\mathrm{NaOH}$ solution to capture $\mathrm{CO}_{2}$; the remaining gas was assumed to be methane. The anaerobic digestion experiments were run for a period of c.a. 20 days until the accumulated gas production remained essentially unchanged. The volume of methane produced was corrected at standard temperature and pressure conditions (STP: $0{ }^{\circ} \mathrm{C}, 1$ atm). The $\mathrm{C} / \mathrm{N}$ ratios of five different mixtures were tested, and ranged from $31.9(100 \%$ OMSW) to 5.6 (100\% microalga). Intermediate C/N ratios like 12.1 (25\% OMSW-75\% S. quadricauda), 18.7 (50\% OMSW-50\% S. quadricauda) and 25.3 (75\% OMSW-25\% S. quadricauda) were also tested.

\section{Analytical methods}

All analyses were performed according to the Standard Methods of APHA (APHA 1998). The following parameters were measured: total chemical oxygen demand (COD), soluble chemical oxygen demand (SCOD), total solids (TS), volatile 
solids (VS), total alkalinity (TA), $\mathrm{pH}$, ammonium concentration $\left(\mathrm{N}-\mathrm{NH}_{4}{ }^{+}\right)$and elemental $\mathrm{C}$ and N. Soluble parameters were determined after sample centrifugation (Eppendorf, $10000 \mathrm{rpm}, 10 \mathrm{~min}$ ) and filtration (glass fiber filter 47mm). Free ammonia concentration was calculated according to the following formula (Østergaard, 1985):

$$
\frac{\left[\mathrm{NH}_{3}\right]}{\left[\mathrm{TNH}_{3}\right]}=\left(1+\frac{10^{-\mathrm{pH}}}{10^{-\left(0.09018+\frac{2729.92}{\mathrm{~T}(\mathrm{~K})}\right)}}\right)^{-1}
$$

where $\left[\mathrm{NH}_{3}\right]$ is the concentration of free ammonia, $\left[\mathrm{TNH}_{3}\right]$ is the total ammonia concentration and $\mathrm{T}(\mathrm{K})$ is the temperature measured in degrees kelvin.

TS and VS were determined according to the standard methods $2540 \mathrm{~B}$ and 2540E (APHA 1998), respectively; COD was determined by the method described by Raposo et al. (2008), while SCOD was determined using the closed digestion and the colorimetric standard method 5220D (APHA 1998). $\mathrm{pH}$ was analyzed using a pH-meter model Crison 20 Basic. TA was determined by $\mathrm{pH}$ titration to 4.3 (APHA 1998). Ammonium was determined colorimetrically according to the phenol-hypochlorite method based on Standard Methods (APHA 1998). C and N were determined through an Elemental Analyzer LECO CHNS-932 (Leco Corporation, St Joseph, MI, EEUU). Individual volatile fatty acids (VFA) from $\mathrm{C} 2$ to $\mathrm{C} 7$ including iso- $\mathrm{C} 4$, iso- $\mathrm{C} 5$ and iso-C6 were analyzed by a Gas Chromatograph (Shimadzu GC 2010) equipped with a flame ionization detector (FID) and a capillary column filled with Nukol (polyethylene glycol modified by nitroterephthalic acid). Prior to injection, $900 \mu \mathrm{L}$ of the sample were mixed with $150 \mu \mathrm{L}$ of $\mathrm{H}_{3} \mathrm{PO}_{4}(1: 2 \mathrm{~V}: \mathrm{V})$ to adjust the $\mathrm{pH}$ to below 2.0 and $150 \mu \mathrm{L}$ of a crotonic acid solution (2000 mg/L) were added as internal standard. This mixture was centrifuged to remove any solids and transferred to a $1500 \mu \mathrm{L}$ gas chromatography (GC) vial; the sample injection volume was $1 \mu \mathrm{L}$. The temperatures of the injector and detector were maintained at 200 and $250{ }^{\circ} \mathrm{C}$, respectively, while the column temperature 
was increased from 120 to $160{ }^{\circ} \mathrm{C}$ at a rate of $10{ }^{\circ} \mathrm{C} / \mathrm{min}$.

\section{Kinetic study}

The Transference Function (TF) model was applied to fit the experimental data of methane production during BMP tests (eq. 2). The transference function (Reaction curve-type model) (RC), used mainly for control purposes, considers that any process might be analyzed as a system receiving inputs and generating outputs (Donoso-Bravo et al. 2010). The TF model was successfully applied by several authors for the biomethanization of different organic wastes (Donoso-Bravo et al. 2010; Li et al. 2012; Pinto-Ibieta et al. 2016). The TF model is given by the following expression:

$$
B=B_{\max } *\left(1-\exp \left[-\frac{R_{\max }(t-\gamma)}{B_{\max }}\right]\right)
$$

where $B\left(\mathrm{~mL} \mathrm{CH}_{4} / \mathrm{g} \mathrm{VS}_{\text {added }}\right)$ is the cumulative specific methane production, $B_{\max }(\mathrm{mL}$ $\mathrm{CH}_{4} / \mathrm{g} \mathrm{VS}_{\text {added}}$ ) is the ultimate methane production, $R_{\max }$ is the maximum methane

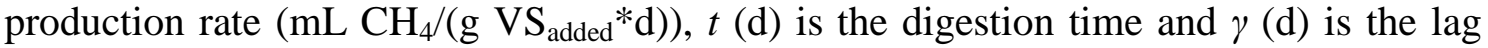
time.

Error (\%), determination coefficient $\left(\mathrm{R}^{2}\right)$ and standard error of estimate were calculated to evaluate the goodness-of-fit and the accuracy of the results. Error was defined as the percentage difference between the experimental and the predicted or theoretical methane yield coefficient. The kinetic parameters for each experiment and mathematical adjustment were determined numerically from the experimental data obtained by non-linear regression using the software Sigma-Plot (version 11).

\section{RESULTS AND DISCUSSION}




\section{Stability of the system}

Due to the great fragility and slow growth rate of methanogenic microorganisms, it is important that the process conditions be sufficiently stable to guarantee maximum methane production during the AD process. The total alkalinity of the system is a parameter related to the buffer capacity of the medium. Alkalinity is influenced by carbonate, ammonium, phosphate, VFA and sulphide subsystem (Xue et al. 2017). Fannin and Biljetina (1987) stablished values between 2500- $5000 \mathrm{mg} \mathrm{CaCO}_{3} / \mathrm{L}$ as ideal for the process of anaerobic digestion. At the end of the experiment, the total alkalinity values ranged from $3471 \pm 176 \mathrm{mg} \mathrm{CaCO}_{3} / \mathrm{L}$ to $6132 \pm 59 \mathrm{mg} \mathrm{CaCO}_{3} / \mathrm{L}(100 \%$ OMSW and $100 \%$ S. quadricauda, respectively) (Table 2). Intermediate total alkalinity values were observed at the end of the experiment for the different co-digestion mixtures: $4889 \pm 245 \mathrm{mg} \mathrm{CaCO}_{3} / \mathrm{L}, 4455 \pm 574 \mathrm{mg} \mathrm{CaCO}_{3} / \mathrm{L}$ and $4804 \pm 115 \mathrm{mg} \mathrm{CaCO} / \mathrm{L}$, for the mixture $75 \%$ OMSW- 25\% S. quadricauda, 50\% OMSW- 50\% S. quadricauda, and $25 \%$ OMSW- $75 \%$ S. quadricauda, respectively (Table 2). The AD of $100 \% S$. quadricauda was the only one that had total alkalinity values higher than those stablished by Fannin et al., ${ }^{23}$ as the optimal value for the stability of AD. The high nitrogen content of microalgae may explain the increase in total alkalinity due to the increased in ammonia concentration, which might initially prove extra alkalinity (Zhang et al. 2016). When the concentration of the ammonia begins to increase, instability and system failure of the $\mathrm{AD}$ process were observed. The adjustment of the $\mathrm{C} / \mathrm{N}$ ratio during co-digestion can minimize this problem.

Volatile fatty acids/ total alkalinity ratios (VFA/TA) is a reliable indicator of process stability in an anaerobic digestion system. When $\mathrm{pH}$ values are between 6 and 8 , the main chemical equilibrium which controls the alkalinity is carbonic acid- 
bicarbonate. In order to avoid the acidification of the reactor, the VFA/TA ratio has to be less than 0.3-0.4 (Iza 1995). In fact, all the VFA/TA ratio values showed during anaerobic co-digestion were clearly lower than 0.3 . In contrast to this, the value of the VFA/TA ratio during anaerobic digestion of $100 \%$ microalga was close to 0.4 . Therefore, co-digestion provided balanced nutrients and prevented the acidification of the AD process. Similar results were reported by Li et al. (2016).

\section{Nitrogen}

The algal cell wall and ammonium toxicity are the main factors to guarantee the optimal biogas production during the $\mathrm{AD}$ of microalgae (González-González et al. 2018). Microalgae have a high nitrogen content $(\mathrm{C} / \mathrm{N}$ ratio $=5.6)$ so it was expected that methane production was inhibited by one of its main methanogen inhibitors, free ammonia (Chen et al. 2008). Thus, $\mathrm{pH}$ and ammonium were measured at the end of the BMP test (Table 2) and free ammonia was calculated on the base of temperature, $\mathrm{pH}$ and ammonium concentration (Østergaard 1985). Free ammonia can be toxic at low concentrations ( $\mathrm{Li}$ et al. 2016) because it easily goes through the bacteria's membrane (Chen et al. 2014).

At the end of the study the $\mathrm{pH}$ ranged between 7.50 and 7.78 in each studied mixture. The ammonium concentrations ranged between $1224 \pm 24 \mathrm{mg} / \mathrm{L}$ at the end of the BMP test of $100 \%$ S. quadricauda and $882 \pm 12 \mathrm{mg} / \mathrm{L}$ measured in $100 \%$ OMSW. The ammonium measured at the end of the BMP test of $100 \%$ microalgae was lower than the limit established (1700-1800 mg/L) in the literature as toxic (Yenigün and Demirel 2013). As a consequence of $\mathrm{pH}$ range, it was expected that the predominant form of inorganic nitrogen was ammonium. Even so, free ammonia was calculated and it was demonstrated that the free ammonia was not a cause of methanogenesis 
inhibition. Ramos-Suárez et al. (2014) observed that the degree of degradation of Scenedesmus cells was very low during the anaerobic co-digestion of Opuntia maxima and Scenedesmus cells. They found low fraction of $\mathrm{N}^{-\mathrm{NH}_{4}}{ }^{+}$during anaerobic codigestion. Mussgnug et al. (2010) showed that Scenedesmus sp. has hardly any biodegradable cell walls that prevent microorganisms from degrading their cell content. Solé-Bundó et al. (2018) did not find much more methane production in their trials despite their pre-treated microalgae to break their cell wall. In contrast, methane production increased when the hydraulic retention time was increased.

\section{Methane yields and study of possible synergic effects}

Figure 1 illustrates the variation in the specific cumulative methane production ( $\mathrm{mL} \mathrm{CH}_{4} \mathrm{STP} / \mathrm{g}$ VS) with digestion time for the BMP assays carried out with $100 \%$ OMSW, $100 \%$ S. quadricauda and for the co-digestion mixtures $75 \%$ OMSW-25\% S. quadricauda, 50\% OMSW-50\% S. quadricauda and 25\% OMSW-75\% S. quadricauda. The highest methane yield after 20 days was $461 \mathrm{~mL} \mathrm{CH} / \mathrm{g}$ VS added for the codigestion of $75 \%$ OMSW-25\% S. quadricauda, while the methane yields obtained for the digestion of the sole substrates were 375 for the AD of the OMSW and $226 \mathrm{~mL} \mathrm{CH}_{4}$ STP/g VS added for the AD of the microalga. The value obtained for the BMP test of $S$. quadricauda was in accordance with previous studies (Mussgnug et al. 2010) Mussgnug et al. (2010) reported Scenedesmus as a microalga with a low degree of decomposition and a high amount of indigestible residues. Nonetheless, the co-digestion of OMSW and S. quadricauda had a high efficiency in methane yield enhancement. The methane yield recorded by Fernández-Rodríguez et al. (2014) from the best co-digestion mixture of 75\% OMSW- 25\% Dunaliella salina was $330 \mathrm{~mL} \mathrm{CH}_{4} / \mathrm{g}$ VS added, lower than the best methane yield obtained in the present study for the co-digestion $75 \%$ OMSW $-25 \% \mathrm{~S}$. 
quadricauda (461 $\mathrm{mL} \mathrm{CH}_{4} \mathrm{STP} / \mathrm{g}$ VS added). Previous research has demonstrated that methane yield from microalgal biomass is highly variable and dependent on the strain used as substrate for anaerobic digestion as well as the growth conditions applied to generate the biomass (Mussgnug et al., 2010). Moreover, the use of saline strains, such as Dunaliella salina has shown that methane production decreases concomitantly with increasing salinity, such as occurred when Dunaliella salina (25\%) was co-digested with OMSW (75\%) (Fernández-Rodríguez et al., 2014).

The experimental methane yields observed for each co-digestion mixture (Figure 1) were compared to calculated methane yields based on the OMSW, and S. quadricauda methane yields separately according to the equation (3).

Calculated methane yield $\left(\mathrm{mL} \mathrm{CH}_{4} \mathrm{STP} / \mathrm{g} \mathrm{VS}\right.$ added $)=$

$\% \mathrm{OMSW}^{*}(375)+\%$ S. quadricauda $*(226)$

Where 375 and 226 are the experimental methane yields $\left(\mathrm{mL} \mathrm{CH}_{4} \mathrm{STP} / \mathrm{g} \mathrm{VS}_{\text {added }}\right)$ obtained for OMSW and S. quadricauda, respectively. \% OMSW and \% $S$. quadricauda are the percentages of OMSW and S. quadricauda, respectively, in each co-digestion mixture. Table 3 summarizes the experimental methane yields obtained for all experiments carried out, as well as the corresponding calculated ones.

Experimental BMP values were higher than the calculated methane yields from equation (3) for some of the co-digestion mixtures tested showing the occurrence of some synergistic effects (Table 3). For instance, $36.3 \%$ for the co-digestion mixture 75\% OMSW-25\% S. quadricauda, 20.6\% for the co-digestion mixture 50\% OMSW$50 \%$ S. quadricauda and 35.4 in the case of the mixture $25 \%$ OMSW-75\% S. quadricauda. Therefore, according to the increase in the BMP values, the 
biodegradability of the above-mentioned co-digestion mixtures was also much higher than the biodegradability of the sole substrates (Table 3 ).

Ajeej et al. (2015) pointed out co-digestion as an effective system of enhancing substrate anaerobic biodegradability. An anaerobic co-digestion study showed that the addition of Dunaliella salina to OMSW improved the biodegradability of the sole substrate (Fernández-Rodríguez et al. 2014). In this study, only 58\% of the available COD was converted to methane during the digestion of $100 \%$ OMSW. The co-digestion mixture $75 \%$ OMSW-25\% S. quadricauda had a biodegradability of $89.5 \%, 91.8 \%$ and $93.2 \%$ for the co-digestion mixture $50 \%$ OMSW-50\% S. quadricauda and $25 \%$ OMSW- $75 \%$ S. quadricauda, respectively. The biodegradability of the $100 \mathrm{~S}$. quadricauda was only $80 \%$. There were clear synergistic effects during the co-digestion of both substrates, since all co-digestions improved the biodegradability of the sole substrate. A clear decrease in the biodegradability was observed when the concentration of OMSW increased. However, despite the increase in microalgae, the biodegradability was similar in each co-digestion mixture.

As can be seen in Table 3, the co-digestion mixture $75 \%$ OMSW-25\% $S$. quadricauda was the combination of the highest methane yield, i.e. $461 \mathrm{~mL} \mathrm{CH}_{4} \mathrm{STP} / \mathrm{g}$ VS. This co-digestion mixture corresponded to a $\mathrm{C} / \mathrm{N}$ ratio of 25.3 , an intermediate value between 20/1 and 30/1 considered as the optimum $\mathrm{C} / \mathrm{N}$ range in the literature (Habiba et al. 2009). In addition, the methane yield obtained from the mixture $75 \%$ OMSW-25\% S. quadricauda was $27 \%$ and $29 \%$ higher than those achieved for the mixtures $50 \%$ OMSW-50\% S. quadricauda and 25\% OMSW-75\% S. quadricauda, respectively. Furthermore, the above-mentioned methane yield obtained from the codigestion mixture $75 \%$ OMSW-25\% S. quadricauda was 23 and 104\% higher than the 
mono-digestion of OMSW (C/N ratio of 31.9) and S. quadricauda (C/N ratio of 5.6), respectively.

It has been previously reported in the literature that the $\mathrm{C} / \mathrm{N}$ ratio is an important factor for anaerobic digestion processes. For instance, Yen and Brune (2007) reported that the co-digestion of a mixture of algal biomass and waste paper ( $50 \%$ based on VS) to keep the $\mathrm{C} / \mathrm{N}$ ratio in a range between $20-30$ doubled the methane production rate with respect to the value achieved for the single algal substrate. In the same way, the anaerobic co-digestion of potato processing waste (PPW) and the microalgae Chlorella vulgaris showed a maximum methane yield of $226 \mathrm{~mL} \mathrm{CH}_{4} / \mathrm{g} \mathrm{VS}$, for the mixture $75 \%$ PPW-25\% Chlorella vulgaris, for which the C/N ratio was 22.7 (Zhang et al. 2019), very similar to the optimum $\mathrm{C} / \mathrm{N}$ ratio obtained in the present work (25.3) for the same co-digestion mixture ( $75 \%$ OMSW- $25 \% S$. quadricauda). It has also been reported that the maximum methane yield during the co-digestion of wheat straw $(80 \%)$ and microalgal biomass (20\%) grown in wastewater was found to be $289 \mathrm{~mL} \mathrm{CH}_{4} / \mathrm{g}$ VS for a $\mathrm{C} / \mathrm{N}$ ratio of 26.4 (Solé-Bundó et al. 2017). These results also showed that the methane yield was increased by $77 \%$ with co-digestion as compared to microalgae mono-digestion. Other studies have demonstrated that co-digestion can also increase the anaerobic digestibility of microalgae by improving the substrate composition. Some cosubstrates can have a co-effect in the sense that they stimulate enzymatic synthesis that can also improve the anaerobic digestion yield (Ajeej et al. 2015). In this sense, sewage sludge improves the digestibility of microalgae and enhances the production of methane when the $\mathrm{C} / \mathrm{N}$ ratios of the co-digestion mixtures achieve values between 20-25 (Ajeej et al. 2015). Other studies have shown that the addition of septic sludge to the microalgae Chlorella sp. resulted in more favorable initial carbon to nitrogen ratios (C/N) (27:1), improved digestibility of algal biomass, and decreased hydrogen 
concentrations, which were directly related to the increased quantity and quality of the methane produced. These results demonstrated the effectiveness of using septic sludge as a co-substrate to anaerobically digest the microalgae Chlorella sp. and enhance biogas production (Lu and Zhang 2016).

\section{Kinetic study}

Table 4 summarizes the parameters obtained from the application of the Transference Function to the experimental data shown in Figure 1.

Among the different co-digestion mixtures assayed, the highest maximum methane

production rate, $R_{m}$, was obtained from the mixture $75 \%$ OMSW-25\% S. quadricauda with a value of $89 \mathrm{~mL} \mathrm{CH}_{4} /(\mathrm{g}$ VS d). This value was $25 \%$ and $39 \%$ higher than those obtained for 50\% OMSW-50\% S. quadricauda and 25\% OMSW-75\% S. quadricauda, respectively. In addition, it was $20 \%$ higher than that achieved through single OMSW (100\% OMSW).

More specifically, a decrease in the maximum methane production rate, $R_{m}$, from 89 to $64 \mathrm{~mL} \mathrm{CH}_{4} /(\mathrm{g} \mathrm{VS} \mathrm{d})$ was observed when the percentage of $S$. quadricauda increased from $25 \%$ to $75 \%$. In the same way, It was recently reported that the values for $R_{m}$ obtained by the co-digestion of Chlorella vulgaris with potato processing waste (PPW) were gradually decreased as the proportions of Chlorella augmented in the mixture from $25 \%$ to $75 \%$ (on VS basis) (Zhang et al. 2019).

On the other hand, the lag periods found in all co-digestion mixtures tested in the present work were very low, and the shape of the curves of methane production with time was almost exponential for all substrates tested. The ammonia release during theco-digestion of increased concentrations of $S$. quadricauda could explain the poorer 
digestion performance and slower kinetics when the percentages of this microalga in the co-digestion mixtures increased (Fernández-Rodríguez et al. 2014).

The co-digestion of microalgal biomass with primary sludge substantially improved the anaerobic digestion kinetics $\left(k=0.25-0.28\right.$ days $\left.^{-1}\right)$ as compared to mono-digestion trials $\left(k=0.07\right.$ days $^{-1}$ for microalgae) (Solé-Bundó et al. 2018). Slight improvements in the degradation kinetics of the mixture of microalgae/bacteria biomass (MAB) grown on piggery wastewater (20\%) with carbonaceous substrates (deproteinated cheese whey and cellulose) (20\%) were observed compared to the digestion of the sole MAB (Carminati et al. 2018). In the same way, it was also reported that the anaerobic codigestion of mixed microalgae (Scenedesmus sp. and Chlorella sp.) (MA) and food waste $(\mathrm{FW})$ at a ratio of 20:80 increased the maximum methane production rate by 2.66 with respect to the microalgae alone (Zhen et al. 2016). The lag phase disappeared in the co-digestion trials; while it was 0.2 days for the pure microalgae. These results again reflect that the co-digestion of microalgae with carbon-rich co-substrates (i.e. food wastes) had a relatively high impact on microalgal anaerobic biodegradability and conversion rate (Zhen et al. 2016).

An implication of this study is that, anaerobic co-digestion of microalgae with OMSW is a promising technology for sustainable energy production. Microalgaebacterial consortium grown in wastewater could reduce costs and be a more sustainable alternative. Moreover, more information about the benefits of several co-substrates in the activity and performance of microbial population in anaerobic co-digestion is necessary. Deeply research in continuous operation is necessary focusing on novel reactor configuration designs that ensure low hydraulic retention times and high organic loading rates. 


\section{CONCLUSIONS}

These results confirmed the powerfulness of the co-digestion of carbon-rich OMSW with nitrogen-rich microalgae. Co-digestion increased the biodegradability of both substrates and the conversion rate. When the microalga Scenedesmus quadricauda was added to OMSW at a percentage of $75 \%$ OMSW- 25\% S. quadricauda (C/N ratio=25.3), the methane yield and the methane production rate were improved compared to the anaerobic digestion of the sole substrates and other co-digestion mixture percentages. Co-digestion also helped the stability of the anaerobic digestion system. The microalga supplied nitrogen to the system, thus balancing the $\mathrm{C} / \mathrm{N}$ ratio and providing extra alkalinity. The transference function model allowed for adequately fitting the experimental results of methane production with time in the anaerobic experiments. Among the different co-digestion mixtures assayed, the highest maximum methane production rate, $R_{m}$, was obtained from the mixture $75 \%$ OMSW-25\% $S$. quadricauda with a value of $89 \mathrm{~mL} \mathrm{CH}_{4} /(\mathrm{g}$ VS d). This value was 25 and $39 \%$ higher than that obtained for 50\% OMSW-50\% S. quadricauda and 25\% OMSW-75\% S. quadricauda, respectively. In addition, this production rate was $20 \%$ higher than that achieved for single OMSW (100\% OMSW).

\section{ACKNOWLEDGMENTS}

The authors wish to express their gratitude to the regional government of Andalucía, Junta de Andalucía, Consejería de Economía y Conocimiento (Project of Excellence RNM1970) for providing financial support. Dr. Rincón-Llorente wishes to thank the "Ramón y Cajal” Program (RYC-2011-08783 contract) from the Spanish Ministry of Economy and Competitiveness for providing financial support. 


\section{REFERENCES}

Ambarsari H, Adrian R, Manurung BS (2018)Anaerobic biogas production using microalgae Chlorella sp. as biomass co-digested by cow manure and cow rumen fluid as inoculum. IOP Conference Series: Earth and Environmental Science.

APHA-AWWA-WPCF (1998) Standard Methods for the Examination of Water and Wastewater, 20th Edition, American Public Health Association, American Water Works Association and Water Environmental Federation, Washington DC.

Ajeej A, Thanikal JV, Narayanan C, Kumar RS (2015) An overview of bio augmentation of methane by anaerobic co-digestion of municipal sludge along with microalgae and waste paper. Rene. Sust Energy 50:270-276.

Barua VB, Rathore V, Kalamdhad AS (2018) Anaerobic co-digestion of water hyacinth and banana peels with and without thermal pretreatment. Renew Energ 103-112.

Carminati P, Gusmini D, Pizzera A, Catenazzi A, Parati K, Ficara E (2018) Biogas from mono- and co-digestion of microalgal biomass grown on piggery wastewater. Water Sci Technol 78 (1):103-113.

Chen Y, Cheng JJ, Creamer KS (2008) Inhibition of anaerobic digestion process: A review. Bioresour Technol 99(10): 4044-4064.

Chen JL, Ortiz R, Steele TWJ, Stuckey DC (2014) Toxicants inhibiting anaerobic digestion: A review. Biotechnol Adv 32(8): 1523-1534.

de la Lama D, Borja R, Rincón B (2017) Performance evaluation and substrate removal kinetics in the semi-continuous anaerobic digestion of thermally pretreated two-phase olive pomace or “Alperujo". Process Saf Environ Prot 105:288-296.

Donoso-Bravo A, Perez-Elvira SI, Fernández-Polanco F (2010) Application of simplified models for anaerobic biodegradability tests. Evaluation of pre-treatment processes. Chem Eng J 160: 607-614.

Fannin KF and Biljetina R (1987) Reactor Design. In: Chynoweth, D.P. and Isaacson, R., Eds., Anaerobic Digestion of Biomass, Elsevier Applied Science, London 109-128.

Fernández-Rodríguez MJ, Rincón B, Fermoso FG, Jiménez AM, Borja R (2014) Assessment of two-phase olive mill solid waste and microalgae co-digestion to improve methane production and process kinetics. Bioresour Technol 157: 263-269.

González-González LM, Correa DF, Ryan S, Jensen PD, Pratt S, Schenk PM (2018) Integrated biodiesel and biogas production from microalgae: Towards a sustainable 
closed loop through nutrient recycling. Renew Sust Energ Rev 82:1137-1148.

Gunay A. and Karadag D (2015) Recent developments in the anaerobic digestion of olive mill effluents. Process Biochem 50(11):1893-1903.

Habiba L, Hassib B, Moktar H (2009) Improvement of activated sludge stabilization and filterability during anaerobic digestion by fruit and vegetable waste addition. Bioresour Technol 100:1555-1560.

Holliger C, Alves M, Andrade D, Angelidaki I, Astals S, Baier U, Bougrier C, Buffière P, Carballa M, De Wilde V, Ebertseder F, Fernández B, Ficara E, Fotidis I, Frigon J, De Laclos HF, Ghasimi DSM, Hack G, Hartel M, Heerenklage J, Horvath IS, Jenicek P, Koch K, Krautwald J, Lizasoain J, Liu J, Mosberger L, Nistor M, Oechsner H, Oliveira JV, Paterson M, Pauss A, Pommier S, Porqueddu I, Raposo F, Ribeiro T, Pfund FR, Strömberg S, Torrijos M, Van Eekert M, Van Lier J, Wedwitschka H, Wierinck I (2016) Towards a standardization of biomethane potential test. Water Sci Technol 74(11): 2515-2522.

Iza J (1995) Control del proceso anaerobio. I Curs d'enginyeria ambiental. Universitat de Lleida. Lleida, 175-201.

Khatib A, Aqra F, Yaghi N, Subuh Y, Hayeek B, Musa M, Basheer S, Sabbah I, (2009) Reducing the environmental impact of olive mill wastewater. Am J Environ Sci 5(1): 16.

Li L, Kong X, Yang F, Li D, Yuan Z, Sun Y (2012) Biogas production potential and kinetics of microwave and conventional thermal pretreatment of grass. Appl Biochem Biotechnol 166: 1188-1191.

Li Y, Li Y, Zhang D, Li G, Lu J, Li S (2016) Solid state anaerobic co-digestion of tomato residues with dairy manure and corn stover for biogas production. Bioresour Technol 217: 50-55.

Lu D, Zhang XJ (2016) Biogas production from anaerobic co-digestion of microalgae and septic sludge. J Environ Eng142 (10): 40-49.

Maamir W, Ouahabi Y, Poncin S, Li H, Bensadok K(2017) Effect of fenton pretreatment on anaerobic digestion of olive mill wastewater and olive mill solid waste in mesophilic conditions. Int J Green Energy14 (6): 555-560.

Mussgnug JH, Klassen V, Schlüter A, Kruse O (2010) Microalgae as substrates for fermentative biogas production in a combined biorefinery concept. J Biotechnol 150(1):51-56. 
Nguyen AQ, Wickham R, Nguyen LN, Phan HV, Galway B, Bustamante H, Nghiem LD (2018) Impact of anaerobic co-digestion between sewage sludge and carbon-rich organic waste on microbial community resilience. Environ Sci: Water Res Technol 4(12):19561965.

Østergaard N (1985) Biogasproduktion i det thermofile temperaturinterval. STUB rapport nr. 21. Kemiteknik. Dansk Teknologisk Institut. Taastrup (in Danish).

Pantziaros AG, Jaho S, Karga I, Iakovides IC, Koutsoukos PG, Paraskeva CA (2018) Struvite precipitation and COD reduction in a two-step treatment of olive mill wastewater. J Chem Technol Biotechnol 93(3): 730-735.

Pinto-Ibieta F, Serrano A, Jeison D, Borja R, Fermoso FG (2016) Effect of Cobalt supplementation and fractionation on the biological response in the biomethanization of olive mill solid waste. Bioresour Technol 211: 58-64.

Ramos-Suárez JL, Martínez A, Carreras N (2014) Optimization of the digestion process of Scenedesmus sp. and Opuntia maxima for biogas production. Energy Convers Manage $88: 1263-1270$.

Raposo F, de la Rubia MA, Borja R, Alaiz M (2008) Assessment of a modified and optimised method for determining chemical oxygen demand of solid substrates and solutions with high suspended solid content. Talanta 76(2): 448-453.

Rippka R, Deruelles J, Waterbury JB (1979) Generic assignments, strain histories and properties of pure cultures of cyanobacteria. J Gen Microbiol 111(1): 1-61.

Rincón B, Sánchez E, Raposo F, Borja R, Travieso L, Martín MA, Martín A (2008) Effect of the organic loading rate on the performance of anaerobic acidogenic fermentation of two-phase olive mill solid residue. Waste Manage 28 (5): 870-877.

Rincón B, Fernández-Rodríguez MJ, de la Lama-Calvente D, Borja R (2018) The Influence of Microalgae Addition as Co-Substrate in Anaerobic Digestion Processes. Microalgal Biotechnology, Eduardo Jacob-Lopes, Leila Queiroz Zepka and Maria Isabel Queiroz, IntechOpen, DOI: 10.5772/intechopen.75914.

Solé-Bundó M, Eskicioglu C, Garfi M, Carrère H, Ferrer I (2017) Anaerobic codigestion of microalgal biomass and wheat straw with and without thermo-alkaline pretreatment. Bioresour Technol 237: 89-98.

Solé-Bundó M, Salvadó H, Passos F, Garfí M, Ferrer I (2018) Strategies to optimize microalgae conversion to biogas: co-digestion, pretreatment and hydraulic retention time. Molecules 23092096. 
Sousa D, Venâncio A, Belo I, Salgado JM (2018) Mediterranean agro-industrial wastes as valuable substrates for lignocellulolytic enzymes and protein production by solid-state fermentation. J Sci Food Agric 98(14): 5248-5256.

Takeda H (1996) Cell wall sugars of some Scenedesmus species. Phytochemistry 42 (3): 673-675.

Wang JY, Liu XY, Kao JCM, Stabnikova O (2006) Digestion of pre-treated food waste in a hybrid anaerobic solid-liquid (HASL) system. J Chem Technol Biotechnol 81: 345351.

Wong YK, Yung KKL, Tsang YF, Xia1 Y, Wang L, Ho KC (2015) Scenedesmus quadricauda for Nutrient Removal and Lipid Production in Wastewater. Water Environ Res 87(12): 2037-2044.

Xiao R, Chen R, Zhang HY, Li H (2011) Microalgae Scenedesmus quadricauda Grown Digested Wastewater for Simultaneous CO2 Fixation and Nutrient Removal. J Biobased Mater Bio 5: 234-240.

Xie S, Higgins MJ, Bustamante H, Galway B, Nghiem L (2018) Current status and perspectives on anaerobic co-digestion and associated downstream processes. Environ Sci: Water Res Technol 4: 1759-1770.

Xu J, Zhao Y, Zhao G, Zhang H (2015) Nutrient removal and biogas upgrading by integrating freshwater algae cultivation with piggery anaerobic digestate liquid treatment. Appl Microbiol Biotechnol 99(15): 6493-6501.

Xue B, Zifu L, Xuemei W, Xi H, Shikun C, Xiaofeng B, Ruiling G (2017) Online measurement of alkalinity in anaerobic co-digestion using linear regression method. Int $\mathrm{J}$ Agric Biol Eng 10(1): 176-183.

Yen HW, Brune DE (2007) Anaerobic co-digestion of algal sludge and waste paper to produce methane. Bioresour Technol 98: 130-134.

Yenigün O, Demirel B (2013) Ammonia inhibition in anaerobic digestion: A review. Process Biochem 48 (5-6): 901-911.

Zhang J, Wang S, Lang S, Xian P, Xie T (2016) Kinetics of combined thermal pretreatment and anaerobic digestion of waste activated sludge from sugar and pulp industry. Chem Eng J 295: 131-138.

Zhang Y, Caldwell GS, Zealand AM, Sallis PJ (2019) Anaerobic co-digestion of microalgae Chlorella vulgaris and potato processing waste: Effect of mixing ratio, waste type and substrate to inoculum ratio. Biochem Eng J 143: 91-100. 
Zhen G, Lu X, Kobayashi T, Kumar G, Xu K (2016) Anaerobic co-digestion on improving methane production from mixed microalgae (Scenedesmus sp., Chlorella sp.) and food waste: Kinetic modeling and synergistic impact evaluation. Chem Eng J 289: 322-341. 
Table 1. Characteristics of the olive mill solid waste (OMSW), Scenedesmus quadricauda ( $S$. quadricauda) and the inoculum used in the experiments. Where TS: total solids, VS: volatile solids, COD: total chemical oxygen demand, SCOD: soluble chemical oxygen demand, TA: total alkalinity, nd: not determined.

\begin{tabular}{llll}
\hline & Values & Values & Values \\
Parameters & OMSW* & S. quadricauda* & Inoculum* \\
\hline $\mathrm{TS}(\mathrm{g} / \mathrm{kg})$ & $267.2 \pm 1.6$ & $99.6 \pm 5.8$ & $32.9 \pm 0.3$ \\
$\mathrm{VS}(\mathrm{g} / \mathrm{kg})$ & $235.1 \pm 0.8$ & $94.0 \pm 3.6$ & $23.7 \pm 0.3$ \\
$\mathrm{COD}\left(\mathrm{g} \mathrm{O}_{2} / \mathrm{kg}\right)$ & $329.8 \pm 1.3$ & $75.5 \pm 2.8$ & $\mathrm{nd}$ \\
$\mathrm{SCOD}\left(\mathrm{g} \mathrm{O}_{2} / \mathrm{kg}\right)$ & $144.4 \pm 2.6$ & $\mathrm{nd}$ & $\mathrm{nd}$ \\
$\mathrm{TA}\left(\mathrm{g} \mathrm{CaCO}_{3} / \mathrm{kg}\right)$ & $2.5 \pm 0.1$ & $\mathrm{nd}$ & $\mathrm{nd}$ \\
$\mathrm{pH}$ & $4.8 \pm 0.2$ & $\mathrm{nd}$ & $6.98 \pm 0.0$ \\
\hline
\end{tabular}

*Concentrations expressed as: weight/weight of wet sample. 
Table 2. Chemical composition of the Biochemical methane potential (BMP) test effluents.

\begin{tabular}{ccccccc}
\hline $\begin{array}{c}\text { OMSW } \\
(\%)\end{array}$ & $\begin{array}{c}\text { S. quadricauda } \\
(\%)\end{array}$ & $\begin{array}{c}\text { TA } \\
\left(\mathrm{mg} \mathrm{CaCO}_{3} / \mathrm{L}\right)\end{array}$ & VFA/TA & pH & $\begin{array}{c}\text { ammonium } \\
(\mathrm{mg} / \mathrm{L})\end{array}$ & $\begin{array}{c}\text { ammonia } \\
(\mathrm{mg} / \mathrm{L})\end{array}$ \\
\hline & & & & & & \\
100 & 0 & $3471 \pm 176$ & 0.30 & 7.78 & $1224 \pm 24$ & 35.9 \\
75 & 25 & $4889 \pm 245$ & 0.22 & 7.67 & $1082 \pm 2$ & 24.8 \\
50 & 50 & $4455 \pm 574$ & 0.25 & 7.65 & $902 \pm 21$ & 19.7 \\
25 & 75 & $4804 \pm 115$ & 0.15 & 7.50 & $935 \pm 25$ & 14.6 \\
0 & 100 & $6132 \pm 59$ & 0.39 & 7.72 & $882 \pm 12$ & 22.6 \\
\hline
\end{tabular}

*OMSW: olive mill solid waste, S.quadricauda: Scenedesmus quadricauda, TA: Total alkalinity, VFA/TA: volatile acids/total alkalinity ratios. 
Table 3. Calculated methane yield values obtained from equation (1), experimental data obtained through BMP test and biodegradability of the different co-digestion mixtures.

\begin{tabular}{|c|c|c|c|c|c|c|}
\hline $\begin{array}{l}\mathrm{C} / \mathrm{N} \\
\text { ratio }\end{array}$ & $\begin{array}{c}\text { OMSW } \\
(\%)\end{array}$ & $\begin{array}{c}\text { S.quadricauda } \\
(\%)\end{array}$ & $\begin{array}{l}\mathbf{B}_{\max } \\
\text { Calculated } \\
\left(\mathrm{mL} \mathrm{CH}_{4} \mathrm{STP} / \mathrm{g}\right. \\
\mathrm{VS})\end{array}$ & $\begin{array}{l}\mathbf{B}_{\max } \\
\text { Experimental } \\
\left(\mathrm{mL} \mathrm{CH}_{4} \mathrm{STP} / \mathrm{g} \mathrm{VS}\right)\end{array}$ & $\begin{array}{c}\text { Methane yield } \\
\text { improvement } \\
\text { (\%) }\end{array}$ & $\begin{array}{c}\begin{array}{c}\text { Biodegradability } \\
\text { (COD-CH }\end{array} \text { / CODadded) } \\
(\%)\end{array}$ \\
\hline 31.9 & 100 & 0 & 375 & 375 & --- & 58.4 \\
\hline 25.3 & 75 & 25 & 338 & 461 & 36.3 & 89.5 \\
\hline 18.7 & 50 & 50 & 301 & 363 & 20.6 & 91.8 \\
\hline 12.1 & 25 & 75 & 263 & 356 & 35.4 & 93.2 \\
\hline 5.6 & 0 & 100 & 226 & 226 & --- & 80 \\
\hline
\end{tabular}

*OMSW: olive mill solid waste, S.quadricauda: Scenedesmus quadricauda, $B_{\max }$ : ultimate methane production 
Table 4: Values for the parameters obtained from the Transference Function model for the different substrates studied.

\begin{tabular}{|c|c|c|c|c|c|c|}
\hline Substrate & $\begin{array}{c}B_{m} \\
\left(\mathrm{~mL} \mathrm{CH}_{4} \mathrm{STP} /\right. \\
\mathrm{g} \text { VS) }\end{array}$ & $\begin{array}{c}R_{m} \\
\left(\mathrm{~mL} \mathrm{CH}_{4} /\right. \\
\mathrm{g} \mathrm{VS} \mathrm{d})\end{array}$ & $\begin{array}{l}\boldsymbol{K} \\
\text { (d) }\end{array}$ & $\mathbf{R}^{2}$ & S.E.E. & $\begin{array}{c}\text { Error }^{* *} \\
(\%)\end{array}$ \\
\hline $100 \%$ OMSW & $381 \pm 8$ & $74 \pm 5$ & 0.0004 & 0.9705 & 27.48 & 1.6 \\
\hline 75\%OMSW-25\% S.q. & $421 \pm 8$ & $89 \pm 5$ & 0.0006 & 0.9763 & 26.72 & 8.6 \\
\hline $50 \%$ OMSW-50\% S.q. & $367 \pm 4$ & $71 \pm 2$ & 0.0001 & 0.9944 & 12.36 & 1.1 \\
\hline 25\%OMSW-75\% S.q. & $351 \pm 3$ & $64 \pm 2$ & 0.045 & 0.9967 & 9.21 & 1.4 \\
\hline $100 \%$ S.q. & $205 \pm 2$ & $115 \pm 8$ & 0.0001 & 0.9869 & 12.02 & 9.2 \\
\hline
\end{tabular}

*S.q.: Senedesmus quadricauda, OMSW: Olive mil solid waste, S.E.E.: Standard error of estimate, $B_{m}$ : ultimate methane production, $R_{m}$ : maximum methane production rate, S.E.E.: standard error of estimate, $\Lambda$ : calculated lag times

$* *$ Error $\left(\left(B_{m \text { experimental }}-B_{m}\right.\right.$ model $\left.) / B_{\text {m experimental }}\right) \cdot 100$ 
Figure 1. Biochemical methane potential ( $\mathrm{mL} \mathrm{CH}_{4} / \mathrm{g}$ VS added) of $100 \%$ olive mill solid waste (OMSW) (-), 100\% Scenedesmus quadricauda (-) and different codigestion mixtures tested: 75\% OMSW-25\% Scenedesmus quadricauda ( $\diamond) ; 50 \%$ OMSW-50\% Scenedesmus quadricauda (A) and 25\% OMSW- $75 \%$ Scenedesmus quadricauda (•).

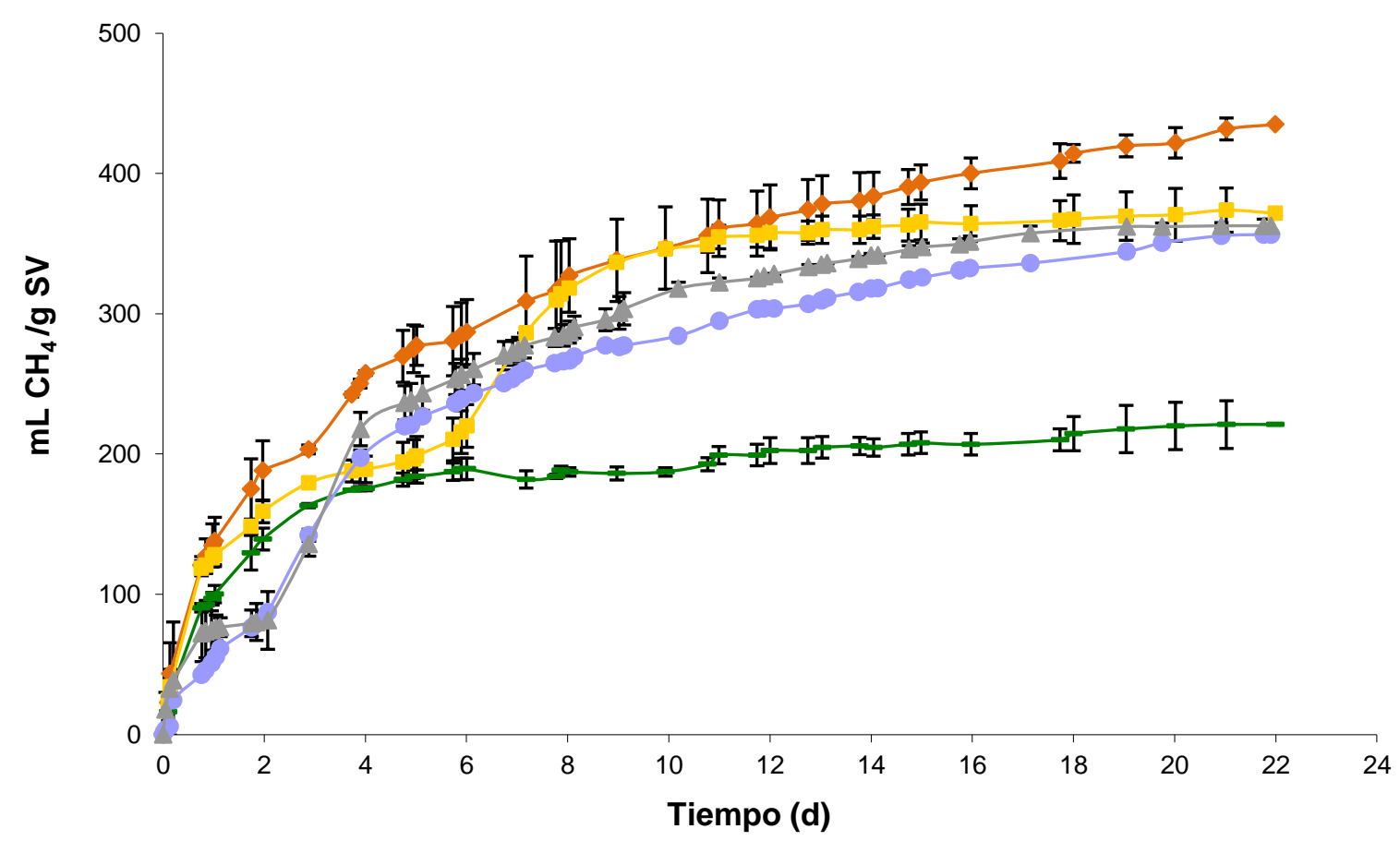


